\title{
Extraction of high purity genomic DNA from pine for use in a high-throughput Genotyping Platform
}

Emily Telfer ${ }^{1 * \dagger}$, Natalie Graham ${ }^{1 \dagger}$, Lisa Stanbra ${ }^{1}$, Tim Manley ${ }^{2}$ and Phillip Wilcox ${ }^{1}$

\begin{abstract}
Standard protocols for extracting genomic DNA from Pinus radiata D. Don needles, such as CTAB-based methods, can yield large quantities of DNA. However, final DNA purity can be an issue due to carry over of contaminants that can impede accurate high throughput genotyping. This study evaluated eight DNA extraction and purification protocols to determine which method provided the greatest improvement in call rates and accuracy when using the Sequenom iPLEX ${ }^{\circledR}$ Gold MassARRAY ${ }^{\circledR}$ genotyping technology. Of the methods tested, genomic DNA extracted using the Machery-Nagel NucleoSpin ${ }^{\circledR}-96$ Plant II kit performed the best overall, and was more efficiently and accurately genotyped than genomic DNA extracted using the standard CTAB method. This study also demonstrated that the quality and assay performance of CTAB-extracted genomic DNA is greatly improved by further purification with the Qiagen ${ }^{\circledR}$ QIAquick 96 PCR Purification kit. Using these improvements, the Sequenom iPLEX ${ }^{\circledR}$ Gold MassARRAY ${ }^{\circledR}$ genotyping technology is now a viable option for genotyping plant genomes such as Pinus radiata.
\end{abstract}

Keywords: Genomic DNA, Genotyping, Pine, Sequenom

\section{Introduction}

New Zealand has approximately 1.8 million hectares of commercial plantation forests, of which $89 \%$ is radiata pine (Pinus radiata D. Don). Radiata pine contributes approximately $2.5 \%$ to New Zealand GDP and has been subjected to intensive breeding and propagation for over 60 years. The integration of molecular approaches into radiata breeding programmes has previously been limited by excessive costs and low throughput. However, the recent advent of mid to high-throughput genotyping technologies has provided researchers with powerful tools to analyse genetic variation for many different applications. These technologies have also created new challenges. Most new technologies are developed and optimised for mammalian systems and do not always transfer to higher plant systems (Chagné et al. 2007), where issues of genome size, abundance of secondary metabolites, and the physical challenge of extracting gDNA from hardy tissues (Palomera-Avalos et al. 2008; Shepherd et al. 2002) need to be overcome. Application of these new genotyping technologies to conifers has been limited,

\footnotetext{
* Correspondence: Emily.Telfer@scionresearch.com

${ }^{\dagger}$ Equal contributors

'Scion, 49 Sala St, Private Bag 3020, Rotorua, New Zealand

Full list of author information is available at the end of the article
}

with only a few reports of such work in pine species in the last three years (Chancerel, et al., 2011; Dillon, et al., 2010; Eckert, et al., 2009).

The success of modern genotyping platforms is critically dependent on the isolation of sufficient high quality DNA (Bayés and Gut, 2011). To date, none of the methods published for plants has proved universally applicable across species, tissue types, and analytical approaches (Varma et al. 2007). One of Scion's standard plant DNA extraction protocols for Pinus radiata needles is based on the method of Cato and Richardson (1996) and uses a CTAB buffer. This protocol has worked well for PCR-based genotyping techniques such as SSRs, however, gDNA extracted using this method has been found to be sub-optimal when assayed with several high-throughput genotyping platforms, including the iPLEX $^{\circledR}$ Gold MassARRAY ${ }^{\circledR}$ (Sequenom Inc., San Diego, CA, USA). This has resulted in high rates of missing genotypes (assay fail rates of $21 \%$ ), incomplete genotypes (64\% of loci departing from HWE) and inaccurate genotypes ( $1 \%$ of genotypes inconsistent across replicates). To address these problems, a search was conducted for an alternative, high-throughput DNA extraction method, yielding gDNA of sufficient quality and quantity for reliable genotyping. The aim of this study was to investigate the efficacy of eight DNA extraction/purification 
techniques compared to the current CTAB method. Some methods were modified versions of Scion's current CTAB method while others were based on proprietary extraction kits which had proved successful for other researchers in pine species using PCR-based approaches (Dillon, et al., 2010; Palomera-Avalos, et al., 2008; Shepherd, et al., 2002). In particular, a reduction in the levels of contaminants such as carbohydrates, phenolics (Barzegari et al. 2010) and guanidine salts (Reithinger et al. 2000) was considered a key outcome as these compounds have been shown to impact on downstream enzymatic applications (Bashalkhanov \& Rajora, 2008).

\section{Materials and methods Extraction and purification}

In stage 1, eight alternative DNA extraction and purification protocols were trialled using pine needle tissue, using the standard tissue input recommendations for each method. The eight DNA extraction and purification protocols trialled are described below, with the key differences between the methods outlined in Table 1 . Five of these (Methods C, CE, CQ, CZ and CG), were adaptations of Scion's standard CTAB-based method (Method S). DNA extracted using Method $S$ with no additional modification was not included in stage 1 . The other three methods, F, D and N, were based on proprietary extraction kits.

\section{Method S: Standard CTAB extraction}

Scion's standard DNA extraction procedure was adapted from Cato \& Richardson (1996). Chopped needle tissue (300 mg) was homogenised with a mortar and pestle under liquid nitrogen, placed into a $2 \mathrm{~mL}$ tube and $1 \mathrm{~mL}$ of pre-warmed $\left(65^{\circ} \mathrm{C}\right)$ CTAB buffer ${ }^{\mathrm{a}}$ added. After one hour incubation at $65^{\circ} \mathrm{C}$, cellular debris was pelleted by centrifugation at $18000 \times g$, and $700 \mu \mathrm{L}$ of supernatant was transferred to a fresh tube containing RNase A at a final concentration of $100 \mu \mathrm{g} / \mathrm{mL}$. After a $30 \mathrm{~min}$ incubation at $37^{\circ} \mathrm{C}, 1 / 5 \times$ volume $5 \mathrm{M} \mathrm{NaCl}$ and $1 \times$ volume chloroform:isoamyl alcohol (24:1) were added, the tube was mixed by gentle inversion and centrifuged at $18000 \times g$ for $20 \mathrm{~min}$. The aqueous phase was removed and re-extracted with another $1 \times$ volume chloroform: isoamyl alcohol. After centrifugation at $18000 \times g$ for $20 \mathrm{~min}$, the aqueous phase was transferred to a fresh tube, $1 \times$ volume ice cold isopropanol added and the DNA precipitated overnight at $-20^{\circ} \mathrm{C}$. DNA was pelleted at $18000 \times g$ for $30 \mathrm{~min}$, washed in $70 \%$ ethanol, and airdried before resuspension in $50 \mu \mathrm{L}$ sterile water.

\section{Method 1: Modified CTAB extraction (C)}

DNA was extracted as per Method S with a few modifications, including homogenisation of the tissue $(150 \mathrm{mg})$ using a Geno/Grinder ${ }^{\mathrm{rm}} 2000$ (Spex SamplePrep, Metuchen, NJ, USA). Approximately $100 \mathrm{mg}$ sea sand (acid-purified and calcined) was added to a $5 \mathrm{~mL}$ polyethylene screw-cap grinding vial containing a $9.5 \mathrm{~mm}$ stainless steel bead (Spex SamplePrep part no. 2240PEF), followed by $150 \mathrm{mg}$ chopped needle tissue, a second bead and $2 \mathrm{~mL}$ of CTAB buffer. Vials were capped, loaded into the Geno/Grinder and run at 1400 strokes/ min for $20 \mathrm{~s} \times 6$, then incubated for $60 \mathrm{~min}$ at $65^{\circ} \mathrm{C}$. Cellular debris was pelleted by centrifugation for $10 \mathrm{~min}$ at $2000 \times g$, and supernatant transferred to a fresh tube containing RNase A at a final concentration of $100 \mu \mathrm{g} /$ $\mathrm{mL}$, and incubated at $37^{\circ} \mathrm{C}$ for $30 \mathrm{~min}$. Subsequent chloroform extraction steps were as described for Method S, but DNA precipitation was performed with room temperature isopropanol, and incubated overnight at room temperature (Michiels et al. 2003). Ethanol washes and final resuspension were as for Method S.

\section{Method 2: Modified CTAB extraction with ethanol/acetate precipitation (CE)}

The DNA extracted using Method $C$ was further purified by an additional ethanol/sodium acetate precipitation. To the resuspended DNA, 1/10× volume $3 \mathrm{M}$ sodium acetate and $2.5 \times$ volumes $96 \%$ ethanol were added, mixed by gentle inversion and incubated at $-20^{\circ} \mathrm{C}$ for 2 hours. DNA was pelleted at $18000 \times g$ for $10 \mathrm{~min}$, washed with $1 \times$ volume $96 \%$ ethanol, and air-dried before resuspension in $50 \mu \mathrm{L}$ sterile water.

\section{Method 3: Modified CTAB extraction with QIAquick ${ }^{\circledR} P C R$ purification (CQ)}

The DNA extracted using Method $C$ was further purified using Qiagen's QIAquick ${ }^{\circledR}$ PCR Purification kit (Qiagen, Düsseldorf, GER) as per manufacturer's instructions, eluting in $60 \mu \mathrm{L}$ buffer EB.

\section{Method 4: Modified CTAB extraction with Genomic DNA Clean and Concentrator ${ }^{\mathrm{TM}}$ purification (CZ)}

The DNA extracted using Method $C$ was further purified using Zymo's Genomic DNA Clean and Concentrator ${ }^{\mathrm{TM}}$ kit (Zymo Research Corporation, Irvine, CA, USA) as per manufacturer's instructions, eluting in $30 \mu \mathrm{L}$ sterile water.

\section{Method 5: Modified CTAB extraction with Genomic-tip 20/G purification (CG)}

The DNA extracted using Method $C$ was further purified using Qiagen's Genomic-tip 20/G kit, as per manufacturer's instructions, applying all recommendations to increase yield. DNA was resuspended in $60 \mu \mathrm{L}$ sterile water. 
Table 1 Comparison of DNA extraction methods

\begin{tabular}{|c|c|c|c|c|c|c|c|c|c|c|}
\hline Method & $\begin{array}{l}\text { Wt. of tissue } \\
\text { (mg) }\end{array}$ & $\begin{array}{l}\text { Homo-genisation } \\
\text { conditions }\end{array}$ & $\begin{array}{l}\text { Extraction buffer } \\
\text { used(vol; temp) }\end{array}$ & $\begin{array}{l}\text { Lysis incubation } \\
\text { conditions }\end{array}$ & $\begin{array}{l}\text { Centrifug-ation } \\
\text { conditions }\end{array}$ & $\begin{array}{l}\text { RNase } \\
\text { A conc. }\end{array}$ & $\begin{array}{l}\text { Incubation } \\
2 \text { conditions }\end{array}$ & $\begin{array}{l}\text { Extraction } \\
\text { conditions }\end{array}$ & $\begin{array}{l}\text { DNA pptn } \\
\text { conditions }\end{array}$ & $\begin{array}{l}\text { Additional } \\
\text { purification }\end{array}$ \\
\hline \multirow[t]{2}{*}{$S$} & 300 & $\begin{array}{l}\text { Pestle \& mortar } \\
\text { under liquid } \\
\text { nitrogen }\end{array}$ & $\begin{array}{l}1 \mathrm{~mL} \mathrm{CTAB} \\
\text { buffer; } 65^{\circ} \mathrm{C}\end{array}$ & $60 \mathrm{~min} ; 65^{\circ} \mathrm{C}$ & $\begin{array}{l}18000 \times 9 \\
20 \min \end{array}$ & $\begin{array}{l}100 \\
\mu \mathrm{g} / \mathrm{mL}\end{array}$ & $\begin{array}{l}30 \mathrm{~min} ; 37^{\circ} \mathrm{C} \\
\text { (RNase A digestion) }\end{array}$ & $\begin{array}{l}\text { (1) } 0.2 \mathrm{vol} 5 \mathrm{M} \mathrm{NaCl}+ \\
1 \mathrm{vol} \mathrm{ClA} \text {; then } \\
18000 \times g \text { min }\end{array}$ & $\begin{array}{l}1 \text { vol cold isopropanol; } \\
-20^{\circ} \mathrm{C} \mathrm{O} / \mathrm{N}^{3} \text {; then } \\
18000 \times g 30 \mathrm{~min}\end{array}$ & None \\
\hline & & & & & & & & $\begin{array}{l}\text { (2) } 1 \mathrm{vol} \mathrm{ClA} \text {; then } \\
18000 \times g 20 \mathrm{~min}\end{array}$ & & \\
\hline C & 150 & $\begin{array}{l}\text { Geno/ Grinder }{ }^{\mathrm{TM}} \\
2000 \text { with sea } \\
\text { sand, } 2 \text { stainless } \\
\text { steel beads }\end{array}$ & $\begin{array}{l}2 \mathrm{~mL} C T A B \\
\text { buffer; } R^{2}{ }^{2}\end{array}$ & $\begin{array}{l}\text { Same as for } \\
\text { Method S }\end{array}$ & $\begin{array}{l}2000 \times g ; \\
10 \mathrm{~min}\end{array}$ & $\begin{array}{l}100 \\
\mu \mathrm{g} / \mathrm{mL}\end{array}$ & $\begin{array}{l}\text { Same as for } \\
\text { Method S }\end{array}$ & $\begin{array}{l}\text { Same as for } \\
\text { Method S }\end{array}$ & $\begin{array}{l}1 \text { vol RT' } \mathrm{RT}^{2} \text { isopropanol; } \\
\mathrm{RT}^{2} \mathrm{O} / \mathrm{N}^{3} \text {; then } \\
18000 \times \mathrm{g} 30 \mathrm{~min}\end{array}$ & None \\
\hline CE & \multicolumn{2}{|c|}{ Same as for Method C } & & & & & & & & $\begin{array}{l}\text { Ethanol/sodium } \\
\text { acetate }\end{array}$ \\
\hline CQ & \multicolumn{2}{|c|}{ Same as for Method C } & & & & & & & & $\begin{array}{l}\text { QIAquick }{ }^{\circledR} \text { PCR } \\
\text { Purification kit }\end{array}$ \\
\hline$C Z$ & \multicolumn{2}{|c|}{ Same as for Method C } & & & & & & & & $\begin{array}{l}\text { Genomic DNA } \\
\text { Clean and } \\
\text { Concentrator }^{\mathrm{TM}} \\
\text { kit }\end{array}$ \\
\hline CG & \multicolumn{2}{|c|}{ Same as for Method C } & & & & & & & & $\begin{array}{l}\text { Genomic-tip } \\
\text { 20/G kit }\end{array}$ \\
\hline $\mathrm{F}$ & $\begin{array}{l}\text { Same as for } \\
\text { Method C }\end{array}$ & $\begin{array}{l}\text { FastPrep }^{\circledR} \\
\text { instrument, tubes } \\
\text { with beads } \\
\text { supplied in kit }\end{array}$ & Kit supplied & $5 \mathrm{~min}$; on ice & $\begin{array}{l}\text { Same as for } \\
\text { Method S }\end{array}$ & None & N/A & Kit supplied & N/A & None \\
\hline $\mathrm{D} \& \mathrm{D}+$ & 50 & $\begin{array}{l}\text { Same as for } \\
\text { Method C }\end{array}$ & Kit supplied & N/A & $\begin{array}{l}\text { Same as for } \\
\text { Method C }\end{array}$ & $\begin{array}{l}250 \\
\mu \mathrm{g} / \mathrm{mL}\end{array}$ & $\begin{array}{l}10 \mathrm{~min} ;-20^{\circ} \mathrm{C} \\
\text { (SDS precipitation) }\end{array}$ & Kit supplied & N/A & None \\
\hline$N \& N 96$ & 100 & $\begin{array}{l}\text { Same as for } \\
\text { Method C }\end{array}$ & Kit supplied & $\begin{array}{l}\text { Same as for } \\
\text { Method S }\end{array}$ & $\begin{array}{l}\text { Same as for } \\
\text { Method C }\end{array}$ & $\begin{array}{l}300 \\
\mu \mathrm{g} / \mathrm{mL}\end{array}$ & $\begin{array}{l}\text { Same as for } \\
\text { Method D }\end{array}$ & Kit supplied & N/A & None \\
\hline
\end{tabular}

${ }^{1}$ Chloroform:isoamyl alcohol (24:1) vol:vol.

${ }^{2}$ Room temperature.

${ }^{3}$ Overnight. 


\section{Method 6: FastDNA ${ }^{\circledR}$ protocol, with modifications (F)}

The DNA was extracted as per manufacturer's instructions (MP Biomedicals, Solon, OH, USA), except for the following modifications: tissue $(150 \mathrm{mg})$ was homogenized in the plant tissue lysis solution for $3 \times 20 \mathrm{~s}$ at speed 5 in the FastPrep ${ }^{\circledR}$ instrument, and immediately placed on ice for $5 \mathrm{~min}$. Cellular debris was pelleted at $13000 \times g$ for $35 \mathrm{~min}$, the supernatant transferred to a fresh tube, and then centrifuged for a further $5 \mathrm{~min}$ at $21000 \times g$. The cleared supernatant was transferred to a fresh tube, and binding matrix added, as per manufacturer's instructions. Pelleting of the binding matrix from the supernatant was performed at $1000 \times g$ for $2 \mathrm{~min}$, and repeated after washing with SEWS-M solution. Residual SEWS-M solution was collected at $1000 \times g$ for $10 \mathrm{~s}$, and removed using a small bore pipette tip. Elution of DNA from the binding matrix was performed at room temperature, and centrifuged at $21000 \times g$ for $5 \mathrm{~min}$ to minimise carry-over of binding matrix when transferring DNA-containing supernatant to the final collection tube.

\section{Method 7: DNeasy ${ }^{\circledR}-96$ protocol, with modifications (D)}

The DNA was extracted as per manufacturer's instructions, except for the following modifications: lysis buffer (AP1, RNase A and Reagent DX) and AP2 buffer volumes were increased $2.5 \times$ to allow for homogenisation of the tissue $\left(50 \mathrm{mg}\right.$ ) with the Geno/Grinder ${ }^{\mathrm{rm}} 2000$ (settings as per Method C). Centrifugation steps were performed at a maximum of $3220 \times g$. Once samples were applied to the DNeasy plate, all subsequent centrifugation steps were replaced with vacuum processing on a QIAvac 96 manifold (Qiagen Düsseldorf, GER).

Method 8: NucleoSpin ${ }^{\circledR}$ Plant Il protocol, with modifications (N) The DNA was extracted as per manufacturer's instructions (Machery-Nagel, Düren, GER), except for the following modifications: increased volumes of lysis buffers (480 $\mu \mathrm{L}$ PL2 and $16 \mu \mathrm{L}$ RNase A, and $115 \mu \mathrm{L}$ PL3) were used, but the relative ratios of the individual buffers were maintained. This was to allow for homogenisation of the tissue $\left(100 \mathrm{mg}\right.$ ) with the Geno/Grinder ${ }^{\mathrm{rM}} 2000$ (as described for Method C). The $65^{\circ} \mathrm{C}$ incubation was increased from 10 min to 1 hour.

For stage 2, further optimisations were applied to methods $\mathrm{D}$ and $\mathrm{N}$ as follows:

\section{Method D+}

The single AW buffer wash step in method D was increased to three washes, and the supplied elution buffer was replaced with $2 \times 50 \mu \mathrm{L} 10 \mathrm{mM}$ Tris (pH 8.5).

\section{Method N96}

The NucleoSpin ${ }^{\circledR}-96$ Plant II plate based method was used instead of the NucleoSpin ${ }^{\circledR}$ Plant II kit with individual spin columns. The DNA was extracted as per manufacturer's instructions, except for the following modifications: volumes of lysis buffers were increased further [773 $\mu \mathrm{L}$ PL2 and $27 \mu \mathrm{L}$ RNase A (total $800 \mu \mathrm{L}$ ), and $200 \mu \mathrm{L}$ PL3], but the relative ratios of the individual buffers were maintained as before. The incubation at $65^{\circ} \mathrm{C}$ was for 1 hour. To clear the lysate after SDS precipitation, two 10 minute centrifugation steps were performed at $2000 \times g$ with the clear supernatant removed after each step. The QIAvac 96 manifold was used for vacuum processing, and the MN Wash Plate was not used. Elution was performed in two steps with 75 and $50 \mu \mathrm{L} \mathrm{PE}$.

A fourth method (SQ), consisting of standard method $\mathrm{S}$ extracted DNA further purified with the Qiagen QIAquick ${ }^{\circledR}$ PCR Purification kit, was included to test if existing DNA stocks could be rescued for use in downstream genotyping experiments. The scaled-up gDNA sample panel was re-designed to contain up to 79 new tree samples.

\section{Quantification and assessment of purity}

After extraction, aliquots of gDNA were labelled with Quant-iT ${ }^{\mathrm{TM}}$ PicoGreen ${ }^{\circledR}$ dsDNA reagent (Life Technologies, Carlsbad, CA, USA) and quantified using a BMG POLARStar Galaxy microplate reader (BMG LabTechnologies, Offenberg, GER) (Table 2). The absorbance of each sample was determined at wavelengths of $230 \mathrm{~nm}$ (the absorbance peak for common non-protein contaminants) and $260 \mathrm{~nm}$ (the absorbance peak for DNA) using a NanoDrop $^{\text {TM }} 1000$ spectrophotometer (Thermo Scientific, Waltham, MA, USA). These values were used to calculate the $\mathrm{A}_{260} / \mathrm{A}_{230}$ ratio of the extracted gDNA as a means to determine average purity for a given method.

\section{Genotyping}

All samples were diluted to $20 \mathrm{ng} / \mu \mathrm{L}$ for use in the iPLEX $^{\circledR}$ Gold MassARRAY ${ }^{\circledR}$ genotyping unless they were not concentrated enough, in which case they were used undiluted. The final sample panel comprised gDNA from each of the 47 tree samples extracted using the eight DNA extraction protocols (methods 1-8). Samples were assayed with iPLEX ${ }^{\circledR}$ Gold MassARRAY ${ }^{\circledR}$ 31-SNP and 27-SNP multiplex assays, developed in previous studies (data not shown). The iPLEX ${ }^{\circledR}$ Gold MassARRAY ${ }^{\circledR}$ system employs a locus-specific PCR followed by allele-specific primer extension to generate products of unique mass, detected by MALDI-TOF. Genotypes (homozygote (AA or BB) or heterozygote $(\mathrm{AB})$ ) for each $\mathrm{SNP}$ are then assigned to each individual (Jurinke et al. 2004).

\section{Method performance}

The performance of the genotyping assay for each method was assessed using three criteria: missing genotypes (assay fail rates), incomplete genotypes (loci departing from HWE) and inaccurate genotypes 
Table 2 Assessment of average DNA yields, purity and Sequenom iPLEX ${ }^{\circledR}$ Gold assay assay performance

\begin{tabular}{|c|c|c|c|c|c|c|c|}
\hline & $\begin{array}{c}\text { Total number } \\
\text { extractions }\end{array}$ & 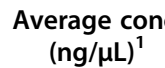 & $\begin{array}{c}\text { Average yield } \\
\text { (ng DNA/mg tissu }\end{array}$ & $\begin{array}{l}\text { Abso } \\
260 \mathrm{~nm}\end{array}$ & & $\% M$ & \\
\hline
\end{tabular}

Standard CTAB DNA extractions

S 1927

$234 \pm 211$

39

ND $20 \mathrm{ng} / \mu \mathrm{L}$ from HWE genotypes ${ }^{4}$

Stage 1: Testing eight methods

$\begin{array}{cc}\text { C } & 47 \\ \text { CE } & 47 \\ C Q & 47 \\ \text { CZ } & 47 \\ C G & 47 \\ \text { N } & 44 \\ \text { F } & 47 \\ \text { D } & 43\end{array}$

$$
\begin{gathered}
413 \pm 34 \\
454 \pm 22 \\
180 \pm 39 \\
232 \pm 33 \\
80 \pm 8 \\
30 \pm 22 \\
52 \pm 49 \\
35 \pm 26
\end{gathered}
$$

138

$1.6 \pm 0.1$
$2.0 \pm 0.1$
$2.0 \pm 0.1$
$2.5 \pm 0.1$
$2.5 \pm 0.5$
$2.1 \pm 0.2$
$0.9 \pm 0.3$
$1.6 \pm 0.4$

2

Stage 2: Scaled up test of four methods

$\begin{array}{cc}\text { SQ } & 70 \\ \text { CQ } & 79 \\ \text { N96 } & 79 \\ \text { D+ } & 77\end{array}$

$\begin{array}{lcl}165 \pm 110 & 33 & 2.6 \pm 0.5 \\ 397 \pm 32 & 159 & 2.3 \pm 0.2 \\ 158 \pm 63 & 198 & 2.2 \pm 0.2 \\ 65 \pm 12 & 191 & 2.9 \pm 1.5\end{array}$

0
0
0
0
9
38
30
37

${ }^{1} \pm$ Standard Deviation.

${ }^{2} \pm$ Standard Deviation. Note: ideal range for A260/A230 ratios is $1.8-2.2$.

${ }^{3}$ Fail rates calculated for all samples across all assays.

${ }^{4}$ Inconsistent genotypes across replicate samples. 
(inconsistent genotypes across replicate samples). Departure from HWE was used as an indicator of genotypic class bias within the assay and was measured with a $\chi^{2}$ test. Significant departure from HWE was indicated by $p$-Values < 0.05 . All eight methods were also tested by a single operator who ranked their ease of use. Using these criteria, along with extraction efficiency and assay performance, three preferred methods (N, D, and CQ) were selected for stage 2, a scaled-up iPLEX ${ }^{\circledR}$ Gold assay.

\section{Results and discussion}

The modified CTAB protocols $\mathrm{C}$ and $\mathrm{CE}$ yielded the highest gDNA concentration (Table 2). Conversely, the NucleoSpin ${ }^{\circledR}$ Plant II (individual columns) (N) and DNeasy ${ }^{\circledR}-96$ (96-plate) (D) extractions produced the lowest concentrations.

Presence of contaminants and low yield can impact the performance of downstream enzymatic applications. However, purity alone or yield alone should not be the sole consideration when comparing methods (Llongueras,
Nair, Salas-Leiva, \& Schwarzbach, 2012), but should be considered in conjunction with assay performance.

Results under an ideal $A_{260} / A_{230}$ ratio of 1.8-2.2 (Table 2) can indicate the presence of carbohydrates and phenolics (co-extractants from pine needles) or guanidine salts (carryover from some commercial extraction buffers). All four methods that included additional purification steps following $\mathrm{CTAB}$ extraction $(\mathrm{CQ}, \mathrm{CZ}, \mathrm{CE}$ and $\mathrm{CG}$ ) produced material with improved average $\mathrm{A}_{260} / \mathrm{A}_{230}$ ratios compared to CTAB extraction alone (C). The average $A_{260} / A_{230}$ ratio for material produced using method $\mathrm{N}$ was also within acceptable limits. Method D and F showed less than acceptable average $A_{260} / A_{230}$ ratios, possibly due to carry-over of guanidine salts from the supplied buffers. Additional wash steps for Method D + were included to mitigate this issue and subsequently the average $A_{260} / A_{230}$ ratio was improved.

Four extraction methods (CG, N, F and D) yielded some samples with concentrations less than $20 \mathrm{ng} / \mu \mathrm{L}$, which were used undiluted in the iPLEX $^{\circledR}$ Gold assay (Table 2). The performance of individual samples for the 8 methods trialled in stage 1 across the 31-plex iPLEX ${ }^{\circledR}$

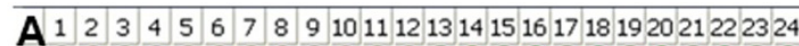
A (1) (1) (2) (2) (3) (3) (4) (4) (5) (5) (6) (6) (1) (1) (2) (2) (3) (3) (4) (4) (5) (6) 6) 6

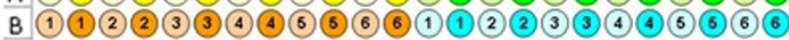
C 7 (7) (8) (8) (9) (9) (10) (10) (11) (11) (12) (12) 7 (7) (8) (8) (9) (9) (10) (10) (11) (11) (12) (12)

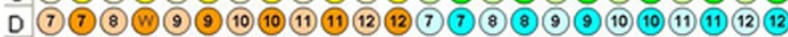
E (13) (13) (14) (14) (15) (15) (16) (16) (17) (17) (18) (18) (13) (13) (14) (14) (16) (15) (16) (16) (17) (18) (18) $F$ (13) (13) (14) (14) (15) (16) (16) (16) (17) (17) (18) (18) (13) (13) (14) (14) (15) (15) (16) (16) (17) (17) (18) (18) G (19) (19) (20) (20)(21) (21) (22) (22) (23) (23) (24) (24) (19) (19) (20) (20) (21) (21) (22) (22) (23) (23) (24) (24) $\mathrm{H}$ (19) (19) (20) (10) (21) (21) (22) (22) (23) (23) (24) (24) (19) (1) (20) (1) (21) (21) 22) (22) (23) (23) (24) (24) I (25) (25) (26) (26) (27) (27) (28) (28) (29) (20) (30) (30) (25) (25) (26) (26) (27) (27) (28) (28) (29) (20) (30) (30) J (25) (25) (26) (26) (27) (27) (28) (28) (29) (20) (30) (30) (25) (25) (26) (26) (27) (27) (28) (28) (29) (20) (30) (30) K (31) (31) (32) (32) (33) (33) (34) (34) (35) (35) (36) (36) (31) (32) (32) (35) (35) (35) (35) (35) L (311 (31) (32) (32) (33) (16) (34) (34) (35) (35) (36) (36) (311) (31) (32) (32) (33) (1) (34) (34) (35) (35) (36) (36) $M$ (37) (37) (38) (38) (39) (39) (40) (40) (41) (41) (42) (42) (37) (37) (38) (38) (39) (39) (40) (40) (41) (41) (42) (42) N (37) (37) (38) (39) (39) (39) (40) (40) (41) (41) (42) (42) (37) (37) (37) (39) (39) (39) (40) (40) (41) (41) (42) (42)

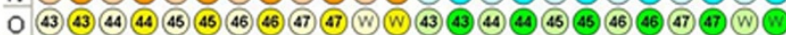
$P$ (43) (43) (44) (44) (45) (45) (46) (45) (47) (47) (1) (4) (43) (43) (44) (45) (45) (46) (47) (47) (1)

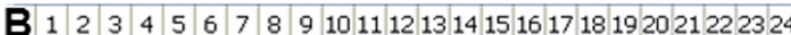
A.00000000000000000000000 B 000000000000000000000000 c 00000000000000000000000

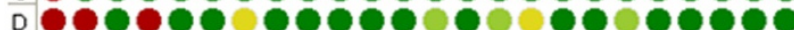
E 000000000000000000000000 F 00000000000000000000000 G 00000000000000000000000 н $100000000000000 \mathrm{l} 00000$ I 0000000000000000000000 j 00000000000000000000000 k000000000000000000000000 L 00000000000000000000000 MO00000000000000000000000 N 100000000000000000000000

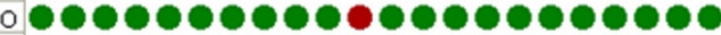
P00000000000000000000000

\begin{tabular}{|c|c|c|c|}
\hline \multicolumn{4}{|c|}{ PLATE LAYOUT FOR 8TEST PROTOCOLS } \\
\hline CODE & Protocol & CODE & Protocol \\
\hline$\bigcirc$ & C & $\bigcirc$ & CE \\
\hline$\bigcirc$ & CQ & $\bigcirc$ & CG \\
\hline$\bigcirc$ & CZ & $\bigcirc$ & F \\
\hline$\bigcirc$ & N & $\bigcirc$ & D \\
\hline
\end{tabular}

\begin{tabular}{|c|c|c|}
\hline \multicolumn{3}{|c|}{ THRESHOLDS FOR ASSAY EFFICIENCY } \\
\hline Well & Default Threshold & Threshold Name \\
\hline$\bigcirc$ & Call rate $\geq 85 \%$ & Optimal \\
\hline$\bigcirc$ & $50 \% \leq$ call rate $\leq 84 \%$ & Above Success \\
\hline$\bigcirc$ & $15 \% \leq$ call rate $\leq 49 \%$ & Below Success \\
\hline$\bigcirc$ & Call rate $\leq 14 \%$ & Failure \\
\hline
\end{tabular}

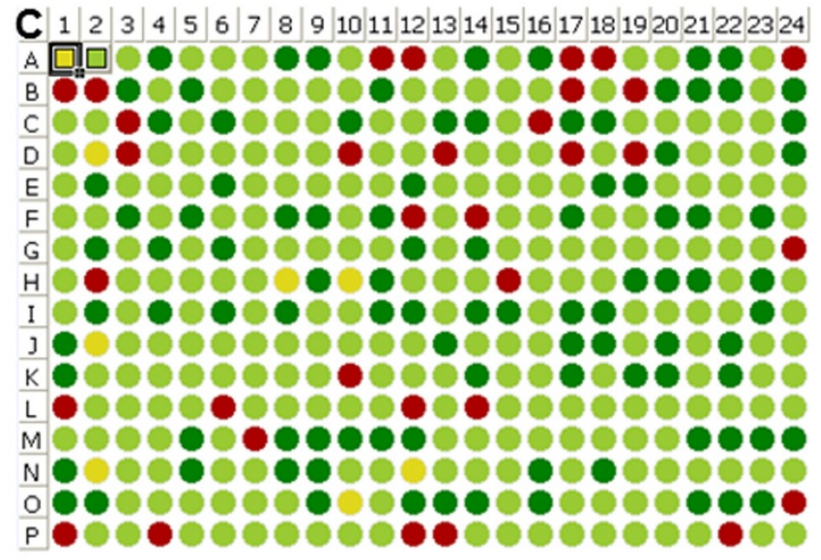

Figure 1 A) 384 well plate layout showing configuration of 47 samples extracted with 8 different protocols in stage 1. B) Assay efficiencies for samples (layout as in A) genotyped with the Sequenom 31-plex assay. C) A representative plate showing assay efficiencies typically seen for Sequenom 31-plex assay using standard CTAB extracted DNA (S). NB: The sample layout for $\mathbf{C}$ is NOT the same as in $\mathbf{A}$ and $\mathbf{B}$. 
Table 3 Additional factors considered for selection in stage 2

\begin{tabular}{|c|c|c|c|}
\hline Criteria & Method CQ & Method N & Method D \\
\hline Relative cost & $\$ \$$ & $\$$ & $\$ \$$ \\
\hline Ease of use & $3 \mathrm{rd}$ & $1 s t$ & 2nd \\
\hline Compatible with Geno/ Grinder ${ }^{\mathrm{TM}} 2000$ & Yes & Yes & Yes \\
\hline \multirow[t]{2}{*}{ Scalable to 96 -well format } & Extraction No & Yes - N96 & Yes \\
\hline & Purification Yes & & \\
\hline
\end{tabular}

Gold assay are shown in Figure 1B. A noticeable increase in performance was observed compared to a representative plate from a previous experiment using DNA extracted with method S (Figure 1C). All methods, except F, showed reductions in fail rates compared to standard CTAB extraction (S) (Table 2). Methods with fail rates less than $10 \%$ in stage 1 were CG, D, CQ, CE and $\mathrm{N}$. Interestingly, methods $\mathrm{D}$ and $\mathrm{N}$ produced material that showed a higher percentage of loci departing from HWE compared to Method C, possibly due to a higher percentage of samples with concentrations less than $20 \mathrm{ng} / \mu \mathrm{L}$. Effective template concentration at a heterozygous locus is approximately half that of a homozygous locus, therefore less than optimal sample concentration can lead to incomplete genotyping of heterozygous individuals. The resulting apparent loss of heterozygotes can be one of the causes of departure from HWE.

In addition to the experimental results of yield, purity and assay performance, we considered the relative ease of use, cost and adaptability to our preferred method of tissue disruption (Geno/Grinder ${ }^{\mathrm{TM}}$ 2000) when selecting methods for stage 2 (Table 3 ).

Of the four methods scaled up in stage 2, gDNA extracted by N96 gave the best results with no inconsistent genotypes, $6.5 \%$ of loci showing significant departure from HWE and an overall fail rate of $8.3 \%$. The N96 method has also performed well in other plant species and genotyping systems (Llongueras, et al., 2012). Comparable fail rates were also achieved with methods CQ and SQ, but the percentage of assays departing from HWE was nearly doubled. Method D showed the highest proportion of missing genotypes, and tended to give the lowest DNA yields of the four methods trialled in stage 2 . These results demonstrate that improvements in the quality of gDNA extracted using the standard method (S) could be achieved with additional purification (e.g. CQ). A similar version of method CQ was recently used to extract $P$. radiata gDNA samples which were successfully genotyped using both the iPLEX $^{\circledR}$ Gold MassARRAY ${ }^{\circledR}$ and an alternative highthroughput platform, the GoldenGate universal bead arrays (Illumina San Diego, CA, USA) (Dillon, et al., 2010). Taking into account assay performance, cost, and ease of use, method N96 has been chosen as our method of choice for future genotyping studies.

\section{Conclusions}

We demonstrated that the accuracy of the iPLEX ${ }^{\circledR}$ Gold MassARRAY $^{\circledR}$ genotyping platform for assaying pine genomic DNA is sensitive to gDNA quality. We observed a dramatic improvement in SNP call quality as determined by three performance criteria (assay fail rate, $\%$ of loci departing from HWE, and \% of inaccurate genotypes) in trials of the different extraction and purification methods. Genomic DNA from Pinus radiata needle tissue was most efficiently and accurately genotyped by the iPLEX ${ }^{\circledR}$ Gold MassARRAY ${ }^{\circledR}$ system when extracted using the NucleoSpin ${ }^{\circledR}-96$ Plant II kit. Although DNA yields were slightly inferior to several other methods, the overall performance of this kit was best. The 96-well format was very efficient compared to our traditional CTAB methods. A less efficient, but comparable level of gDNA purity and performance could also be achieved by passing CTAB extracted gDNA through a QIAquick ${ }^{\circledR}$ PCR Purification kit. These findings were applied to our large association experiment $(\mathrm{N}=1927)$ and fail rates of less than $10 \%$ were achieved, improved from $21 \%$ in the original experiment (data not shown).

\section{Endnote}

a 2\% CTAB, 8\% NaCl, 20 mM EDTA, 0.1 M Tris- $\mathrm{HCl}$, $1 \%$ polyvinylpyrrolidone, $0.2 \% \beta$-mercaptoethanol, $0.5 \mathrm{mg} /$ $\mathrm{mL}$ proteinase $\mathrm{K}$.

\section{Abbreviations}

CTAB: Cetyl trimethylammonium bromide; DNA: Deoxyribonucleic acid; EDTA: Ethylenediaminetetraacetic acid; gDNA: Genomic DNA; HWE: HardyWeinberg equilibrium; MALDI-TOF: Matrix-assisted laser desorption/ ionization-time of flight; PCR: Polymerase chain reaction; SDS: Sodium dodecyl sulfate; SNP: Single nucleotide polymorphism; SSR: Simple sequence repeats; Tris: Tris(hydroxymethyl)aminomethane.

\section{Competing interests}

The authors declare that they have no competing interests.

\section{Authors' contributions}

ET analysed the genotyping data and drafted the manuscript. NG performed and assessed the DNA extraction methods, and helped to draft the

manuscript. LS provided technical advice and provided critical revisions of the manuscript. TM carried out the genotyping and provided technical advice. PW contributed to the conception and technical design of the study, and provided critical revisions of the manuscript. All authors read and approved the final manuscript. 


\section{Acknowledgments}

We thank Glenn Thorlby and Rebecca McDougal for insightful review of this work. We would also like to thank our anonymous reviewers and in-house editors for improving this manuscript. This work was funded by the New Zealand Ministry of Science \& Innovation grant CO4X0703.

\section{Author details}

${ }^{1}$ Scion, 49 Sala St, Private Bag 3020, Rotorua, New Zealand. ${ }^{2}$ Formerly of

AgResearch, Invermay Agricultural Centre, Mosgiel, New Zealand.

Received: 4 February 2013 Accepted: 4 February 2013

Published: 18 March 2013

\section{References}

Barzegari, A, Vahed, SZ, Atashpaz, S, Khani, S, \& Omidi, Y. (2010). Rapid and simple methodology for isolation of high quality genomic DNA from coniferous tissues (Taxus baccata). Molecular Biology Reports, 37(2), 833-837.

Bashalkhanov, S, \& Rajora, OP. (2008). Protocol: A high-throughput DNA extraction system suitable for conifers. Plant Methods, 4(1).

Bayés, M, \& Gut, IG. (2011). Overview of genotyping (pp. 1-23). John Wiley \& Sons, Ltd: Molecular analysis and genome discovery.

Cato, SA, \& Richardson, TE. (1996). Inter- and intra-specific polymorphism at chloroplast SSR loci and the inheritance of plastids in Pinus radiata D.Don. Theoretical and Applied Genetics, 93, 587-592.

Chagné, D, Batley, J, Edwards, D, \& Forster, JW. (2007). Single nucleotide polymorphisms in plants. In N Oraguzie, EHA Rikkerink, SE Gardiner, \& HN De Silva (Eds.), Association mapping in plants (pp. 77-94). New York: Springer Verlag.

Chancerel, E, Lepoittevin, C, Le Provost, G, Lin, YC, Jaramillo-Correa, JP, Eckert, AJ Wegrzyn, JL, Zelenika, D, Boland, A, Frigerio, J, Chaumeil, P, Garnier-Géré, P, Boury, C, Grivet, D, González-Martínez, SC, Rouzé, P, Van de Peer, Y, Neale, DB, Cervera, MT, Kremer, A, \& Plomion, C. (2011). Development and implementation of a highly-multiplexed SNP array for genetic mapping in maritime pine and comparative mapping with loblolly pine. BMC Genomics, 12. doi:10.1186/1471-2164-12-368.

Dillon, SK, Nolan, M, Li, W, Bell, C, Wu, HX, \& Southerton, SG. (2010). Allelic Variation in Cell Wall Candidate Genes Affecting Solid Wood Properties in Natural Populations and Land Races of Pinus radiata. Genetics, 185(4), 1477-1487. doi:10.1534/genetics.110.116582.

Eckert, AJ, Pande, B, Ersoz, ES, Wright, MH, Rashbrook, VK, Nicolet, CM, \& Neale, DB. (2009). High-throughput genotyping and mapping of single nucleotide polymorphisms in loblolly pine (Pinus taeda L.). Tree Genetics and Genomes, 5(1), 225-234.

Jurinke, C, Oeth, P, \& van den Boom, D. (2004). MALDI-TOF Mass Spectrometry. Molecular Biotechnology, 26, 147-163.

Llongueras, JP, Nair, S, Salas-Leiva, D, \& Schwarzbach, AE. (2012). Comparing DNA Extraction Methods for Analysis of Botanical Materials Found in Anti-Diabetic Supplements. Molecular Biotechnology, 1-8. doi:10.1007/s12033-012-9520-0.

Michiels, A, Van Den Ende, W, Tucker, M, Van Riet, L, \& Van Laere, A. (2003). Extraction of high-quality genomic DNA from latex-containing plants. Analytical Biochemistry, 315(1), 85-89.

Palomera-Avalos, V, Castro-Félix, P, \& Villalobos-Arámbula, AR. (2008). High yield and high quality DNA from vegetative and sexual tissues of Mexican white pine (Pinus ayacahuite). African Journal of Biotechnology, 7(1), 051-054.

Reithinger, R, Lambson, BE, Barker, DC, \& Davies, CR. (2000). Use of PCR to detect Leishmania (Viannia) spp. in dog blood and bone marrow. Journal of Clinical Microbiology, 38(2), 748-751.

Shepherd, M, Cross, M, Stokoe, RL, Scott, LJ, \& Jones, ME. (2002). High-throughput DNA extraction from forest trees. Plant Molecular Biology Reporter, 20(4), 425a-425f.

Varma, A, Padh, H, \& Shrivastava, N. (2007). Plant genomic DNA isolation: An art or a science. Biotechnology Journal, 2(3), 386-392. doi:10.1002/biot.200600195.

doi:10.1186/1179-5395-43-3

Cite this article as: Telfer et al: Extraction of high purity genomic DNA from pine for use in a high-throughput Genotyping Platform. New Zealand Journal of Forestry Science 2013 43:3.

\section{Submit your manuscript to a SpringerOpen ${ }^{\odot}$ journal and benefit from:}

- Convenient online submission

- Rigorous peer review

- Immediate publication on acceptance

- Open access: articles freely available online

- High visibility within the field

- Retaining the copyright to your article

Submit your next manuscript at $\gg$ springeropen.com 